\title{
Note on Anomalous Bulbils in a Lily.
}

\author{
BY \\ M. L. GREEN, B.A. \\ With two Figures in the Text.
}

BULBILS 'taken from the stem of Lilium Fortunei giganteum ${ }^{1} 4$ feet from ground ' were sent to Kew by Messrs. Little and Ballantyne for examination. They afforded a very interesting case for investigation, as they had formed flowers in situ, and these flowers showed various degrees of abnormality. Three bulbils were examined with the following results. The first contained five fleshy bulbil scales, five perianth leaves on which were some reddish excrescences, and five stamens (Fig. I, A-E). Various degrees of transition were exhibited in this flower between bulbil scales and perianth leaves, and also between bulbil scales and stamens. Fig. I, D, shows that the perianth leaves have thickened bases which are obviously of the nature of bulbil scales. The stamens in the same flower were not uniform in size and shape. Some of them were normal. One stamen (Fig. 2, G) showed a little abnormality in having a frontal petaloid appendage springing from the connective. This appendage was adnate to the filament for a short distance. Another stamen (Fig. 2, H) was still more abnormal in having a thickened base of the nature of a bulbil scale, a filament of the texture and form of a perianth leaf, and an anther at the apex. The petaloid filament had two lobes and a central ridge of tissue on which was a little crest. This crest is homologous with the petaloid appendage seen in Fig. 2, G. The differentiation of parts in the flower just described was on the whole distinct. In the other two bulbils, however, this was far from being the case : they consisted, like the previous one, of five fleshy scales, but most of them represented transition stages between bulbil scales and perianth leaves. Then came five members, some of which resembled perianth leaves and others stamens, the transitional stages being more advanced than in the first bulbil examined. On some of these lastmentioned perianth leaves were excrescences similar to those mentioned above. The excrescences seem to be homologous with the papillae at the

1 Lilium Fortunei, Lindl. = Lilium tigrinum, var. Fortunei. It is doubtful what is meant by ' Lilium Fortunei giganteum'. 
base of the perianth leaves in Lilium tigrinum and other species, although, of course, they are in a very undeveloped state. The arrangement of parts in these flowers is spiral (Fig. 2, J) instead of cyclic as in the normal flower. In all cases examined the pistil was very rudimentary.
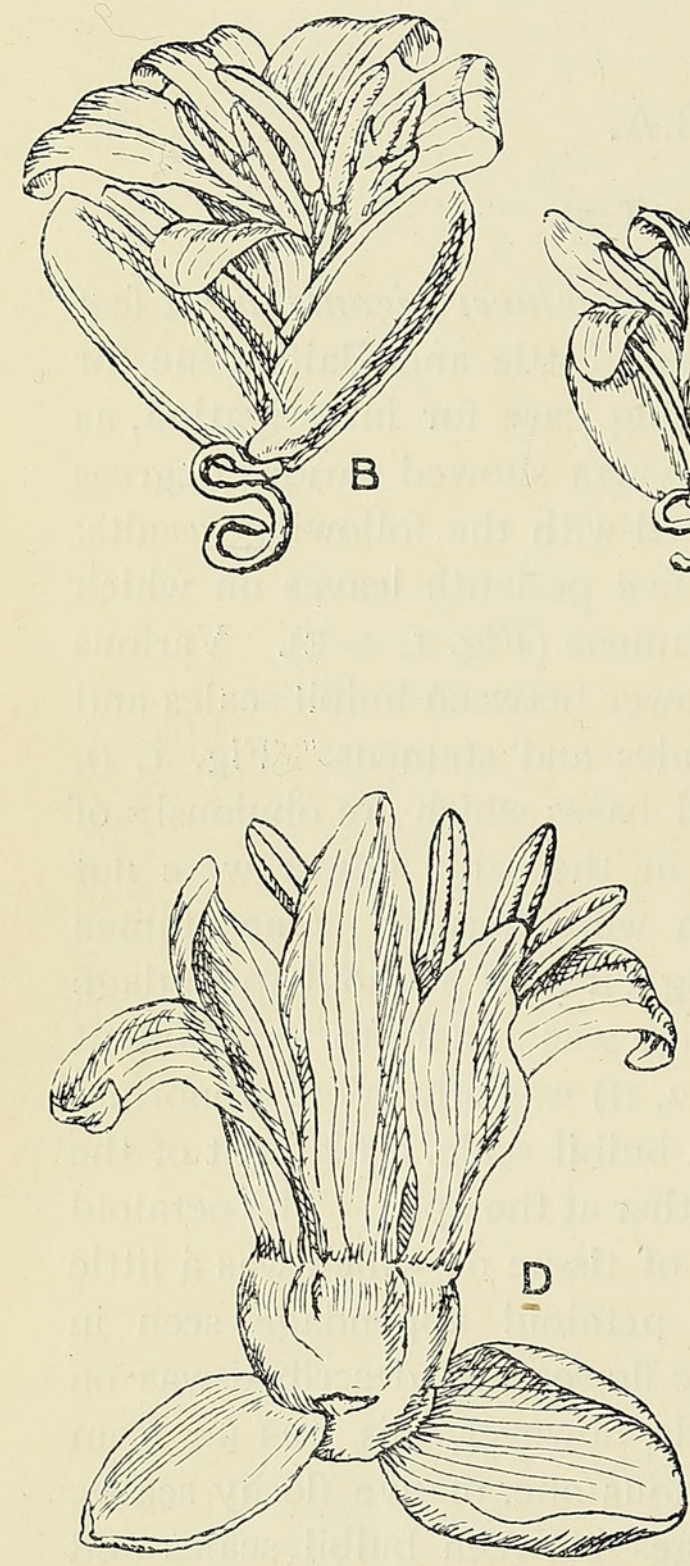

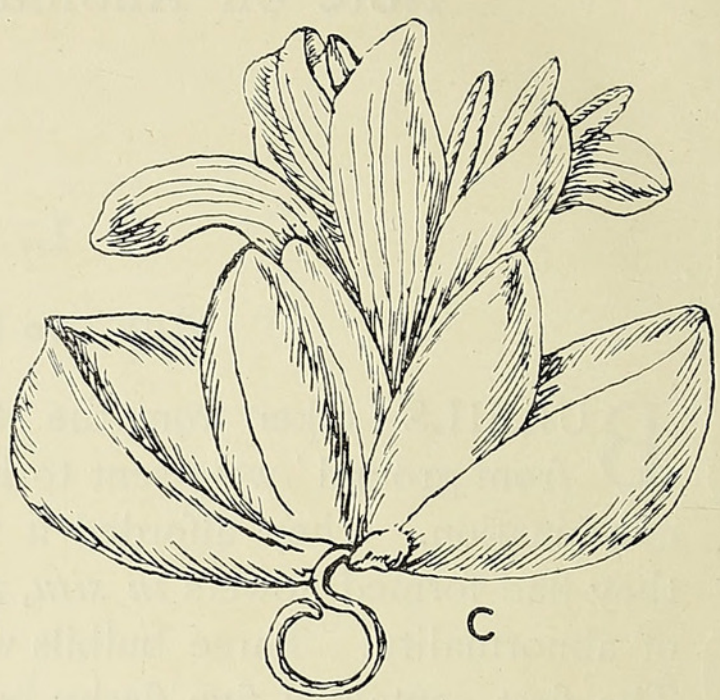

A
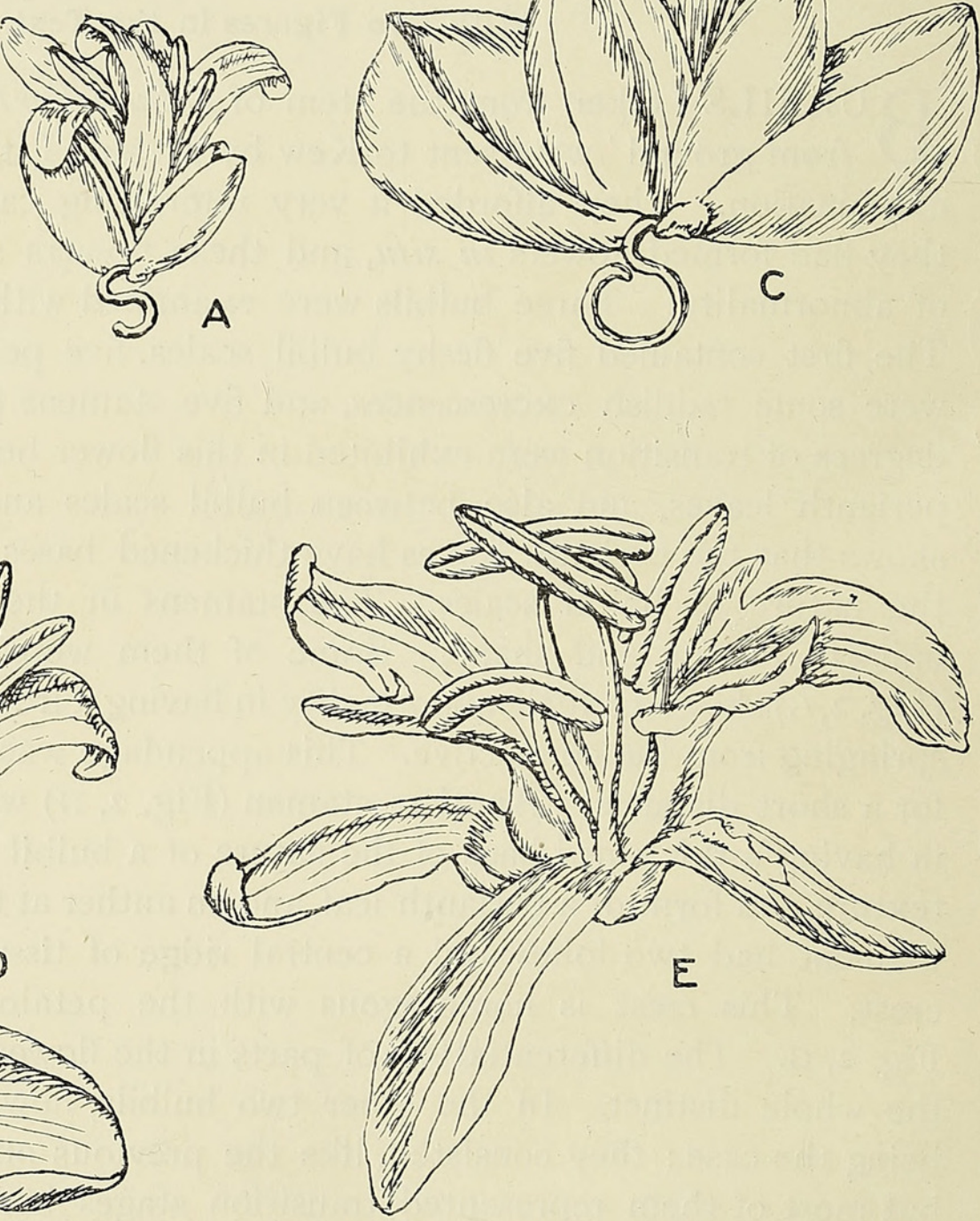

FIG. I. A, Bulbil, natural size. B, another view of the same, $\times 2$. C, the same as B, but showing particularly the five bulbil scales. D, Two bulbil scales removed, showing the perianth leaves with their swollen bases. E, Perianth leaves drawn back exhibiting the stamens.

The question arises as to the morphological value of the bulbils. Are they to be regarded as vegetative organs or as representing flowers? The latter hypothesis is supported by the following considerations:

I. The bulbils were situated on the stem, namely, 4 feet from the ground, evidently in or near the inflorescence. 
2. The stem of Lilium does not, under normal conditions, branch vegetatively, so the bulbils could scarcely represent condensed vegetative shoots.

3. A somewhat similar anomaly has been recorded for Gagea arvensis by Wirtgen in Flora, 1846 , pp. $353^{-68}$, where the bulbils undoubtedly represent abortive flowers. A few details of this anomaly may be interesting here.

The bulbils usually appeared at the base of the main axis of the inflorescence in the leaf axils and represented the lower flowers. Some of the bulbils produced stalks, and these in turn bore flowers. Several single

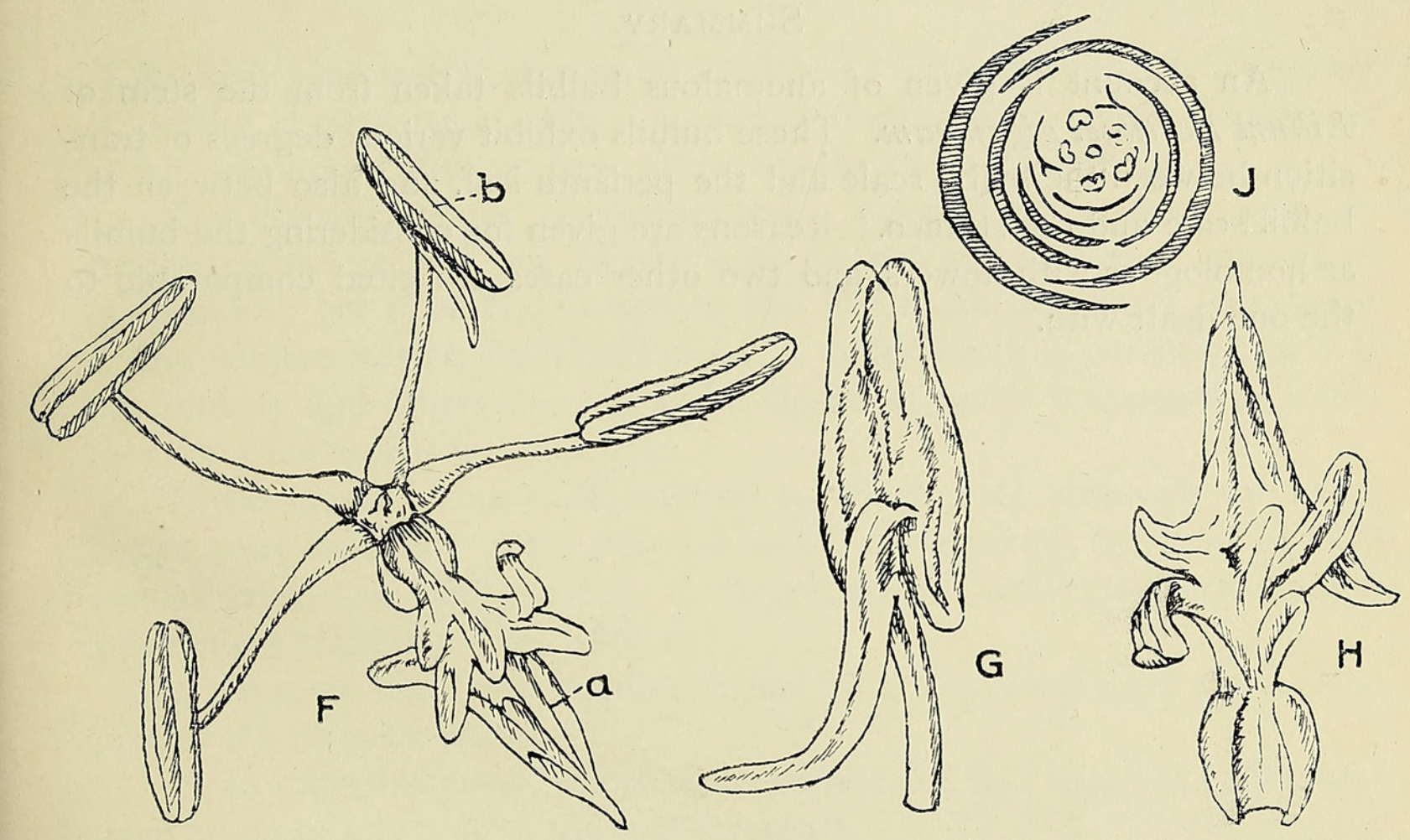

Fig. 2. F, Stamens enlarged. G, Stamen $b$ enlarged, showing anterior petaloid appendage. H, Stamen $a$ showing the transition between bulbil scale and stamen (front view). J, Floral diagram showing spiral arrangement of flower.

small bulbils on the ramifications of short-flower stalks were observed which bore abortive flowers, and this the writer considers to be a clear indication that most of these bulbils are to be regarded as undeveloped or abortive flowers. Further, there also existed on the same inflorescence a transition from the rudimentary flower to the bulbil. The bulbil flowers were by no means uniform, varying in a similar manner to those described above.

4. The only strictly comparable case to the one under consideration is described by $\mathrm{H}$. Hesselman in Act. Hort. Bergiani, Band III, No. I A, pp. I-I9, under the title, 'Ueber die Ausbildung von Bulbillenblättern als florale Blätter bei Lilium bulbiferum, L.'

In this instance the bulbils were sessile in the leaf axils, those in the $\mathrm{B} \mathrm{b}$ 
upper axils occurring along with the flowers. The outermost I-3 leaves of all the bulbils were normal bulbil scales. The lower bulbils had inside these some pale, slightly sepal-like leaves, but no stamens, whereas the upper ones had, in addition to sepal-like leaves, thin and broadened perianth leaves with the fiery red colour of Lilium bulbiferum, and from one to four stamens. Some of the stamens were like a bulb-scale at the base, with a filament and anther above, whilst others were normal.

My thanks are due to Mr. W. C. Worsdell for valuable help and suggestions during the preparation of this note.

\section{SUMMARY.}

An account is given of anomalous bulbils taken from the stem of Lilium Fortunei giganteum. These bulbils exhibit various degrees of transition between the bulbil scale and the perianth leaf, and also between the bulbil scale and the stamen. Reasons are given for considering the bulbils as homologous with flowers, and two other cases are cited comparable to the one dealt with. 


\section{$2 \mathrm{BHL}$ Biodiversity Heritage Library}

Green, Mary Leticia. 1914. "Note on anomalous bulbils in a lily." Annals of botany 28, 355-358. https://doi.org/10.1093/oxfordjournals.aob.a089510.

View This Item Online: https://www.biodiversitylibrary.org/item/236856

DOI: https://doi.org/10.1093/oxfordjournals.aob.a089510

Permalink: https://www.biodiversitylibrary.org/partpdf/320028

\section{Holding Institution}

Smithsonian Libraries

\section{Sponsored by}

Biodiversity Heritage Library

\section{Copyright \& Reuse}

Copyright Status: Not in copyright. The BHL knows of no copyright restrictions on this item.

This document was created from content at the Biodiversity Heritage Library, the world's largest open access digital library for biodiversity literature and archives. Visit BHL at https://www.biodiversitylibrary.org. 